\title{
Changes Required in Saudi Universities Curriculum to Meet the Demands of 2030 Vision
}

\author{
Nadia Yusuf ${ }^{1}$ \\ ${ }^{1}$ Economics Department, King Abdulaziz University, Jeddah, Saudi Arabia \\ Correspondence: Nadia Yusuf, Economics Department, King Abdulaziz University, Jeddah, Saudi Arabia. Tel: \\ 966-567-617-431. E-mail: nyusuf@kau.edu.sa
}

Received: June 20, 2017

Accepted: August 5, 2017

Online Published: August 10, 2017

doi:10.5539/ijef.v9n9p111

URL: https://doi.org/10.5539/ijef.v9n9p111

\begin{abstract}
The evaluation of changes required in the Saudi universities curriculum to meet the demands of 2030 vision has been focused in the study. The qualitative research design has been employed to evaluate existing issues, prevailed among the students in Saudi universities. Systematic review has been adopted as a research method to identify the gaps in existing curriculum and associated problems within Saudi Universities. The findings revealed that there are certain barriers that may influence the implementation of the vision 2030 adversely in Saudi Arabia. Therefore, recommendations based on the analysis have been made, which included future research studies to be conducted that may look into more areas of educational sector. The results represented that there are certain barriers that may influence the implementation of vision 2030 adversely in Saudi Arabia. Therefore, the study has made recommendations, which include conducting future investigations that will explore further fields.
\end{abstract}

Keywords: curriculum, vision 2030, universities, Saudi Arabia

\section{Introduction}

Saudi Arabia competes in the global economy by building educated and skilled workforce. The effective communication between different nations and people across the world is helpful in cultural exchange, peace prevalence, and good welfare. It is necessary to learn foreign languages, particularly English to carry out successful communication (Al-Zahrani et al., 2017). Among different countries, ethnicities, and races across the world, English language has been regarded as a common source of communication. Moreover, different factors are responsible for the prosperity of countries worldwide, and it depends on effective communications (Al-Zahrani et al., 2017). His Royal Highness (HRH) Prince Mohammed bin Salman bin AbdulAziz is the deputy Crown Prince of Saudi Arabia instigated "The Saudi Vision of 2030". This vision includes many aspects among which the establishment of a prominent educational system is the most important aspect. It aims to form a joint association between the government and different businesses to overcome the hardships experienced in communicating globally.

Vision 2030 aims to transform Saudi economy to a balanced and investment based model. The Saudi vision of 2030 has also aimed to search for common grounds to create association between Saudi Arabia and different countries of the world in the educational, economic, and medical fields. According to vision 2030, the improvement and advancement in the educational environment of Saudi Arabia's government schools are associated with development of English language teachings (Al-Zahrani et al., 2017). The effective implementation of vision 2030 depends on effective training of different educational cadres, which are required for teaching English language. The obstacles in learning English language should be overcome to achieve success in development of effective strategies for learning English language (Alrabai, 2016).

The teachers are required to have effective trainings and academic processing for teaching English language, even if the teachers are highly qualified. In order to improve the teaching curriculum according to vision 2030, the teachers need to adopt a specific mechanism to render continuous professional development (Alrabai, 2016). However, overall evaluation of English language teachers in Saudi Arabia revealed unsatisfactory results on the basis of performance among secondary and intermediate level students (Saidi, 2009). There are different professional development methods introduced by the Ministry of Higher Education for the development of effective teaching practices in accordance with vision 2030. 
In Saudi educational system, the teaching methodologies of the teachers negatively affect the English language performance of students. There is a lack of educational competence for the teachers as they face many obstacles in their teaching practices (Al-Zahrani et al., 2017). Therefore, there is a need to develop a foundation of consistent English language teaching with vision 2030 for achieving higher levels in educational system of Saudi Arabia. This study has investigated the changes, required in the prevailing educational system of Saudi Arabia to meet the demands of vision 2030. Moreover, the study has identified the reasons and obstacles that negatively influence the development of performance in teaching English language and achievements of students in learning English language. On the basis of these reasons, the study has evaluated the changes that are essential to meet the demands of vision 2030. The changes required in the prevailing curriculum of Saudi universities to meet the demands of vision 2030 have been focused in this study.

\subsection{Research Questions}

1) What is the effective curriculum that needs to be adopted by teachers to achieve Saudi vision of 2030?

2) What are the factors that lead to positive changes in achieving the objectives of vision 2030 ?

\section{Literature Review}

Vision 2030 is mainly focused towards various economic reforms, cultural projects, and business investment endeavors. However, it is not possible to implement cultural, business, and economic reforms within the country without implicating quality education. English language has been known as one of the significant key factors that are helpful to attain success and maintain international economic relations. It is a common language, which helps in communication between people belonging to different languages and cultures (Al Mukhallafi, 2014). It also helps in building cultural and political relationship with countries worldwide. The main obstacle faced by the students is the lack of motivation among them to learn English language (Mohammed, 2015; Rajab \& Al-Sadi, 2015). A student needs to clear a test at certain level before getting enrolled in an academic specialization like the undergraduate course. Therefore, significant attention has been given to different academic studies by the Saudi Ministry of Education (Ur Rahman \& Alhaisoni, 2013).

The success and continuity of international economic relationships significantly depend on the English language. According to Alrabai (2016), the English language classes in Saudi Arabia for teachers are helpful in adaptation of role as facilitators of learning. However, the students/learners totally depend on the teachers as the major source of knowledge. A study conducted by Altwaijri (1982) revealed that the students from Saudi government schools have been studying English language since 10 years, but their performance is not satisfactory. Therefore, most of the students lack the skills and motivation of learning English language, who are admitted in university programs after passing from high schools (Alrashidi \& Phan, 2015; Al-Nasser, 2015). There is an immediate need of conducting various academic projects and search for improved teaching qualities at the Saudi government schools to implement the objectives and aims of vision 2030. Saudi Arabia needs to take advantage from the knowledge, expertise, and skills of the school going children for successful implementation of vision 2030 (Saidi, 2009).

\subsection{Vision 2030 in Saudi Arabia}

The economy of Saudi Arabia needs to undertake transformation into an oil-dependent economy due to the decrease dependency of the country on oil revenues. In order to restructure country's economy, Saudi government has formulated several measures. Vision 2030 announced by (HRH) Prince Mohammed bin Salman is one of the important measures that resulted in a huge economic transformation after the foundation of Saudi Arabia in 1932 (Yusuf \& Atassi, 2016). In future, there will be a restructuring of curriculum prevailing in Saudi Arabia on the basis of this vision. The changes in curriculum after vision 2030 will be reflected through the transformation of challenges in educational system to ensure effective educational opportunities and quality leap in learning English language skills (Al-Sulami, 2016; Yusuf \& Atassi, 2016).

There is a lack of prominent studies regarding the issue because the announcement of vision 2030 has been made recently in 2016. The development of English language teaching skills was presented at the First International Conference on teaching English language. Different issues regarding improvement in learning English language skills according to 2030 vision were discussed in the conference (Al-Zahrani et al., 2017). The basic aim of the conference was to establish association between different experiences and cultures, which would reflect the objectives of vision 2030. The basic aim of this vision can be achieved through transformation of the challenges into various investment opportunities, which helps in achieving national transformation. It might also help in the establishment of learning centers for English language to raise the quality of performance by utilizing the national standards, which guarantee educational opportunities (Al-Sulami, 2016). 
An insight for future is required on the basis of the educational needs of students and current economic situation of the country. The learning of a language needs significant professional, personal, and academic skills. Therefore, the students need to master in a language by completely engaging the language in the academics and labor market (Al-Sulami, 2016). The maximum investment attracted in the educational sector helps in establishing an effective training environment. Fatani (2016) investigated two major factors that might help in attaining English language training skills in accordance with the 2030 vision;

- Collaboration, cooperation, and participation is required to get out of professional isolation and achieve a common goal.

- The problems related to teaching and learning can be solved by participating on social networking platforms.

\section{Method}

Qualitative approach has been incorporated to evaluate the changes that are required in the university curriculum followed in Saudi Arabia to meet demands of vision 2030. The prevailing educational system in Saudi Arabia has been evaluated thoroughly, and the educational needs of students along with insight for professional and academic skills after vision 2030 have been highlighted. The attitudes and perceptions of teachers in Saudi government schools were identified, which are necessary in achieving the objectives of vision 2030. The teaching requirements in Saudi government schools have been analyzed in accordance with vision 2030 by reviewing the previous studies.

\section{Results}

Table 1. Systematic review

\begin{tabular}{|c|c|c|c|}
\hline Researcher & Target & Methodology & Conclusion \\
\hline lshuwaikhat & $\begin{array}{l}\text { An assessment was done in public sector } \\
\text { universities of Saudi Arabia to assist } \\
\text { Saudi universities in realizing the main } \\
\text { objectives for attaining preservation of } \\
\text { resources and protection of the natural } \\
\text { environment as contained in the vision } \\
2030 \text {. } \\
\text { As envisioned in Saudi Vision 2030, } \\
\text { broader goals for environmental } \\
\text { sustainability can be gained by the } \\
\text { transformation of Saudi universities into }\end{array}$ & $\begin{array}{l}\text { Assessments were conducted, } \\
\text { recruiting different public sector } \\
\text { universities based on } 5 \text { components } \\
\text { including curriculum and teaching } \\
\text { Scholarship; research and campus } \\
\text { operations, Community and } \\
\text { management, and Financial } \\
\text { management }\end{array}$ & $\begin{array}{l}\text { In comparison with the universities of } \\
\text { developed world, there is lack of offerings of } \\
\text { sustainability related academic courses. Saudi } \\
\text { universities still require to enhance the } \\
\text { research and scholarship in the area of } \\
\text { sustainable campus operations in the existing } \\
\text { scenario. There is no prioritization and } \\
\text { sustainable financial management practices } \\
\text { within universities according to the results. } \\
\text { Sustainable practices must be adopted by } \\
\text { Saudi universities as recommended }\end{array}$ \\
\hline
\end{tabular}
center of excellence to contribute in achieving the goals.

Alebaikan The study targeted the perceptions of the Qualitative research design has The study concluded that in Saudi Arabia, (2010) challenges, advantages, and future of been implemented to obtain blended learning has the ability to provide a blended learning. The main factors that descriptive and empirical data to successful learning experience. There have influence the perceptions of advantages, facilitate the identification of been challenges of adoption always when a future and challenges of blended learning. phenomena. The data was analyzed novel approach is implemented. The research Therefore, the main factors that have based on interpretative philosophy has provided understanding into how the influence on the students and teachers in the form of interpretation and challenges of blended learning have been discussed for future research, explanation of the perceptions of implementation could be addressed in Saudi practices and technology. $\quad$ blended learning. universities.

A theoretical blended learning Blended learning environment provides Saudi framework was presented to learners the suppleness to endure their higher deliver the aspects that effect the education and sustaining their own social execution of blended learning. $\quad$ values and customs.

Khan (2011) The study has focused on the motivation Qualitative Research design was Learning barriers are extremely serious in the of students and teachers, commitment and employed to evaluate the general educational settings. It is due to the fact that dedication, teacher's characteristics and barriers to the participation in many graduates and universities failed to gain role, teaching strategies, and professional education including lack of the educational targets fundamentally. and training development. The study motivation and focused teaching, Learning barriers are common in 
considered Saudi Arabia for many inappropriate target curriculum, teaching-learning conditions during daily reasons, and government has found learning barriers and faculty pedagogic/educational activities. Therefore, it spending a lot of money on educational transfer of learning. seems important for planners, policy makers, sector. Still, the learning achievements are not satisfactory. The study targeted the effect of factors on academic achievement, which probably lead to possible solutions. The strategies are expected to reduce the chance of waste and results with maximum educational administrators and curriculum designers to take the matter into consideration to diagnose the learning barriers properly. Many Saudi institutions and language centers frequently experienced these kinds of issues. It is important to deal with variables to yield appropriate educational output.

output, particularly in Saudi Arabia

The study intended to identify the degree Descriptive approach has been Majority of the respondents expressed their of the readiness of EFL teachers in employed by using a survey seriousness in maintaining their academic and interacting with the needs of important instrument, which comprised of 19 scientific level to be in line with the vision transformation at Saudi government items divided into 4 constructs.550 2030 for the development of educational institutions that may lead to the female and 450 male teachers were procedures, more specifically for the enhancement of the performance in line recruited in the study from the promotion of English language teachings. It is with achieving the vision 2030. The Saudi government institution. The apparent from the analysis that teachers of barriers and causes of failures among the data collected was then analyzed English language have a higher level of learners have been identified in the quantitatively. academic awareness, concerning the performance of EFL teachers. development of English language teachings to the learners in line with vision 2030

\section{Discussion}

Considering Saudi Arabia, Khan (2011) suggested that neither teachers nor students are motivated properly towards educational goals. This might be due to inappropriate curriculum in the universities of the Kingdom. The administration of the universities has been observed to motivate teachers and learners. Materialistic and non-materialistic incentives are being provided by the government for teachers. The issue of commitment and dedication towards educational sector of Saudi Arabia is a common issue, which needs to be taken into consideration for Vision 2030. There must be well-defined roles of the teachers, and they must act accordingly in the educational system. The teacher should be taken as an administrator, curriculum designer, facilitator and planner. Such professionals must be considered as first and foremost person, which is responsible to think and plan to do needful (Khan, 2011).

Table 2. Factors responsible for underachievement among university students (Source: Ezza, 2013)

\begin{tabular}{lll}
\hline & \multicolumn{2}{c}{ Factors } \\
\hline High or low expectations of others & Personality of the student & Attention deficit disorder and Learning disability \\
Text tension/ anxiety & Family variables & Numerous medical complications \\
Learning issues & School environment Intervention styles & Psychological problems \\
Fear of problems & Preferred learning style & Emotional problems \\
Lack of motivation & & Academic problems \\
Peer Pressure & \\
Negative attitude towards school & & \\
Lack of experience & & \\
Forced choice dilemma & \\
Missed basic skills & \\
Low academic self-efficacy & & \\
\hline
\end{tabular}

The study by Ezza (2013) suggested the teaching strategies to gain two objectives, which include the motivation for students and helping them to achieve their novel skills. It has been concluded that majority of the students are capable to foster and enhance academically. It is required to ensure that they are guided and informed well to discover the abilities. The study further identified the factors that are responsible for the underachievement of students, which are presented in table 2. The results concerning different studies have suggested that Saudi universities still need to improve the research and scholarship in the area of sustainable operations within 
campus to target the vision 2030. There is a need to attain sustainable practices in terms of university environment, which may enable the students to eradicate the barriers in the way of developing strategies for future betterment. Blended learning environment could be one of the major part of the curriculum as it was found much appreciated by the learners. It may assist the learners to preserve their own tradition and customs in the educational sector. Learning barriers have also been found as one of the main reason of unsustainable environment within universities in Saudi Arabia. Students must be motivated by their teachers, as teachers have been considered as the main person, who facilitates the students. Curriculum plans are also headed by the teachers; so there must be strategies implemented by them to ensure the feasibility of education and eradicate lack of motivation from them. Students were observed to target the vision 2030 in maintaining their academic and scientific level; whereas, promotion of English language was also favored by the learners.

\subsection{Limitations and Future Recommendations}

The study was limited to the universities and educational institutions of Saudi Arabia. The students and their issues concerned with educational system have been evaluated to merely focus on the changes needed in the educational curriculum to meet the demands of vision 2030. The improvement in educational system of Saudi Arabia has been focused from the perspective of vision 2030. Moreover, the requirements for teachers in the enhancement of educational system for attaining the goals have been highlighted from the Saudi vision 2030 perspective. Future research must recruit teachers and professors, who are interconnected with the curriculum maintenance of the universities in Saudi Arabia. Sample size may also be selected with random sampling procedure to recruit the study participants. Quantitative analysis of the responses may be beneficial to have accurate and precise results. Future research may also focus on the teacher's perspective to evaluate the scarcity of educational management in Saudi Arabia, which may assist to enhance the steps taken for attaining vision 2030.

\section{Acknowledgments}

The author is very thankful to all the associated personnel in any reference that contributed in/for the purpose of this research. Further, this research holds no conflict of interest and is not funded through any source.

\section{References}

Al Mukhallafi, T. R. (2014). Computer assisted language learning for learning English in Saudi Arabia.

Alebaikan, R. A. (2010). Perceptions of blended learning in Saudi universities.

Al-Nasser, A. S. (2015). Problems of English language acquisition in Saudi Arabia: An exploratory-cum-remedial study. Theory and Practice in Language Studies, 5(8), 1612. https://doi.org/10.17507/tpls.0508.10

Alrabai, F. (2016). Factors underlying low achievement of Saudi EFL learners. International Journal of English Linguistics, 6(3), 21. https://doi.org/10.5539/ijel.v6n3p21

Alrashidi, O., \& Phan, H. (2015). Education context and English teaching and learning in the Kingdom of Saudi Arabia: An overview. English Language Teaching, 8(5), 33. https://doi.org/10.5539/elt.v8n5p33

Alshuwaikhat, H. M., Adenle, Y. A., \& Saghir, B. (2016). Sustainability Assessment of Higher Education Institutions in Saudi Arabia. Sustainability, 8(8), 750. https://doi.org/10.3390/su8080750

Al-Sulami, A. (2016). The First International Conference of English Languages Concludes Its Sessions in Jeddah. Sabq Electronic Journal.

Altwaijri, A. O. (1982). The adequacy of students' preparation in English as a foreign language in the Saudi schools (Doctoral dissertation, University of Oregon).

Al-Zahrani, N. O. A., \& Rajab, H. (2017). Attitudes and Perceptions of Saudi EFL Teachers in Implementing Kingdom of Saudi Arabia's Vision 2030. International Journal of English Language Education, 5(1), 83-99. https://doi.org/10.5296/ijele.v5i1.10733

Ezza, E. S. Y. (2013). Intervention Strategies in a Saudi English Classroom at Majma'ah University. Journal of Arts and Humanities, 2(2), 17-24.

Fatani, S. A. (2016). Reflections: 10 Challenges to Address in order to Improve the Teaching of English Language in Education to Fulfill the 2030 Vision.

Khan, I. A. (2011). An Analysis of Learning Barriers: The Saudi Arabian Context. International Education Studies, 4(1), 242-247. https://doi.org/10.5539/ies.v4n1p242 
Mohammed, A. (2015). EFL effective factors: Anxiety and motivation and their effect on Saudi College student's achievement. Arab World English Journal, 6(2), 201-218. https://doi.org/10.2139/ssrn.2834391

Rajab, H., \& Al-Sadi, A. (2015). An empirical study of reading habits and interests of Saudi university EFL learners. International Journal of Linguistics, 7(2), 1-16. https://doi.org/10.5296/ijl.v7i2.7034

Saidi, A. (2009). Activating the Role of Educational Supervision in Training English Language Teachers (Master's Dissertation), Umm Al-Qura University, Makkah, Saudi Arabia.

Ur Rahman, M. M., \& Alhaisoni, E. (2013). Teaching English in Saudi Arabia: Prospects and challenges. Academic Research International, 4(1), 112.

Yusuf, N., \& Atassi, H. (2016). Beyond Oil - The Transformation to a Market-Based Approach: Envision Saudi Arabia 2030. Journal of Economics and Sustainable Development, 7(14), 20-24.

\section{Copyrights}

Copyright for this article is retained by the author(s), with first publication rights granted to the journal.

This is an open-access article distributed under the terms and conditions of the Creative Commons Attribution license (http://creativecommons.org/licenses/by/4.0/). 